\title{
動画像の時間・空間情報を利用した動領域セグメンテーショ ンとトラッキング
}

\author{
Video Segmentation and Moving Objects Tracking Using Spatio-Temporal \\ Information
}

\author{
池田 研二†, 一 今 村 幸 祐 ${ }^{\dagger}$, 正会員 橋 本 秀 雄 ${ }^{\dagger}$
}

Kenji Ikeda ${ }^{\dagger}$, Kousuke Imamura ${ }^{\dagger \dagger}$ and Hideo Hashimoto ${ }^{\dagger \dagger}$

あらまし 本速報では，動きと輝度情報を用いた動画像領域分割について検討する．視覚的に意味のあるオブジェクト に分割することで，画像の編集・加工が可能となる．今回，フレーム毎に独立に領域分割する方法と，トラッキングを用 いた領域分割について述べる.

キーワード : Morphological Filter, オプティカルフロー, トラッキング, 領域分割

\section{1. まえがき}

近年，インタネットやモバイルネットワークなどディジ タル動画像を扱うプラットフォームが増え, それに合わせ た伝送方式やアプリケーションが必要になり，より高度な 動画像処理技術が求められている. その 1 つに連続画像中 のオブジェクトを抽出する技術があり，オブジェクトある いは領域に基づいた動画像の符号化が次世代符号化として 研究中である. MPEG-4ではVOP(Video Object Plane) 構造, オブジェクトを構成するブロック単位の動き補償, オブジェクト形状の符号化などが標準化されているが，才 ブジェクトの抽出そのものは標準化の対象外となっている. 動領域を識別するための情報として画像信号の空間・時間 的変化を用いる方法が主流となっており, 特に動領域分割 においては画像の時間的変化である動き情報が重要な要素 になる. 具体的な手法として, ブロック単位に動きを検出 し，似通った動きをもつブロックをクラスタリングする方 法1)では, ブロック単位の精度であるために正確なオブジェ クトの境界は得られない。一方, 画素単位に動きを推定す る方法では, 動領域分割とその動き推定は表裏一体の問題 であることから，これらを結合した確率モデルからべイズ 推定により同時最適化を行う手法 ${ }^{2) 3}$ がある. これは最良の

2002 年 3 月 1 日受付, 2002 年 5 月 1 日再受付, 2002 年 5 月 16 日採録 †金沢大学 大学院 自然科学研究科

（（９20-8667 金沢市小立野 2-40-20, TEL 076-234-4894) †金沢大学 工学部

（干 920-8667 金沢书小立野 2-40-20, TEL 076-234-4894)

† Graduate School of Natural Science \& Technology, Kanazawa Uni-

versity

(2-40-20, Kodatsuno, Kanazawa-shi, Ishikawa, 920-8667, Japan)

†† Faculty of Engineering, Kanazawa University

(2-40-20, Kodatsuno, Kanazawa-shi, Ishikawa, 920-8667, Japan)
結果を与えると期待されるが, 処理量が膨大であり, 現時 点では実用の域に達していない.

本論文では, 画素単位の動き推定としてオプティカルフ ローを使い，輝度情報による領域分割法 ${ }^{455}$ に組込んだ繰り 返し処理を必要としない領域分割法を提案する. 画素単位 のオプティカルフローにより, ブロック単位の動きに比べ てオブジェクトの形状に沿った滑らかな動き推定が行える が, 動領域の境界付近で正確な境界を決定できるほどの精 度を得るのは困難である. そこで, 提案する方法では, 輝 度情報を用いて動領域の境界だけでなく, 絵柄なごの画像 内で濃淡変化の大きい部分を境界として抽出し, 細かなセ グメントに分割する. その後, オプティカルフローの動き 情報を用いて類似した動きを持つセグメント同士を統合さ せ, 動領域分割を行ゔ ${ }^{6}$. また, 画像シーケンスのフレー 厶毎に，この領域分割法を適用すると，処理量が増大する ほかに, 前後フレームの分割結果において領域の対応関係 が明らかでないので, 領域をトラッキングすることにより, 順次, 連続フレームの領域分割を行う方法を提案する.

\section{2. 領域統合型動画像領域分割アルゴリズム}

アルゴリズムの入力情報として以下の前処理が施された 情報を用意する. 原画像に Morphological Filter 処理を施 した画像の輝度情報, 動き情報に 1 画素単位の動きべク トルであるオプティカルフローを用いる. アルゴリズムは 図 1に示す 3 つのステップか.ら成る. ステップ 1 の境界抽 出では輝度情報から画像中の輝度变化の高い境界を抽出 し，多数のセグメントに分割する. ステップ 2 の小領域除 去では 1 つのオブジェクトを構成しえない小さなセグメン 卜を隣接領域に統合させセグメント数を減らす. 最後にス 


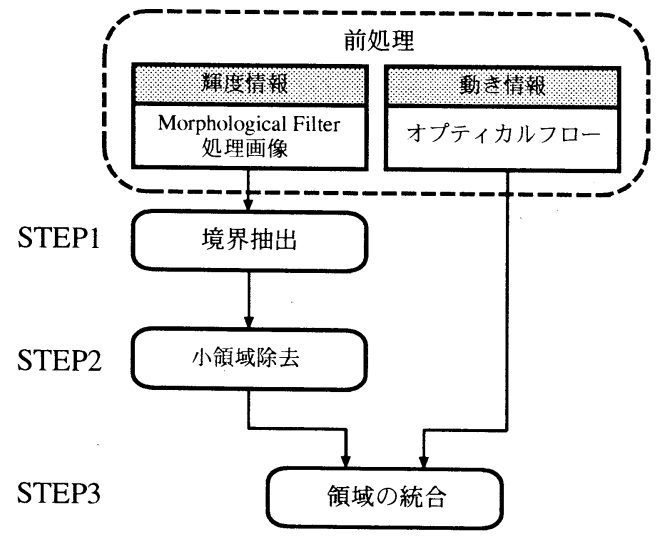

図 1 領域分割アルゴリズム

Algorithm of moving objects segmentation

テップ 3 の領域統合で，オプティカルフローの動き情報と Morphological Filter 処理画像の輝度情報から輝度と動き の類似度が大きい領域同士を統合させ最終的な領域分割を 行う.

\section{1 前処理}

\section{Morphological Filter 処理}

画像の領域分割に必要のない雑音成分や局所的な細かな 情報を取り除く.このような処理を行う簡単なフィルタと して, メディアンフィルタや平均值フィルタがあるが，こ れらのフィルタを使用した場合，才ブジェクトのエッジま でぼけさせるという欠点がある．領域分割ではオブジェク トの輪郭は正確に保つ必要があり，このような現象は望ま しくない. そこで大きな輪郭は残し，かつ細かな絵柄を取 り除く非線形フィルタとして Morphological Filter を用い $る^{7)}$.

\section{オプティカルフロー検出}

動領域分割では, 動領域に対する動き検出を正確に行う ことが重要であり，精度の高い動き検出アルゴリズムが必 要である. 動き検出手法の 1 つであるオプティカルフロー は画素単位に動きを検出するため複雑な形状のオブジェク トの動きも検出できる.オプティカルフローの導出には, 画像輝度值の空間的変化と時間的変化を利用した輝度勾配 法を用い, 画像の輝度値は, 微小時間経過しても変化しな いという輝度值の保存性と画素の動きべクトルは空間的に 滑らかに変化するという仮定から画素単位の動きベクトル を求める ${ }^{8)}$.

\subsection{Watershed アルゴリズムを用いた境界決定}

領域分割において領域の形状を表す境界を抽出するため に計算の簡単さとエッジの正確さから Watershed アルゴ リズムを用いる．図 2 は Watershed アルゴリズムの概念 図である.まず, Morphological Filter 処理画像の輝度值 から, 輝度勾配画像を作成する. 画像中の境界線は輝度変 化が大きい部分であり, 輝度勾配が極大点を持つ部分であ る.つまり, 輝度勾配画像において勾配の極大点を調べる $1350(142)$

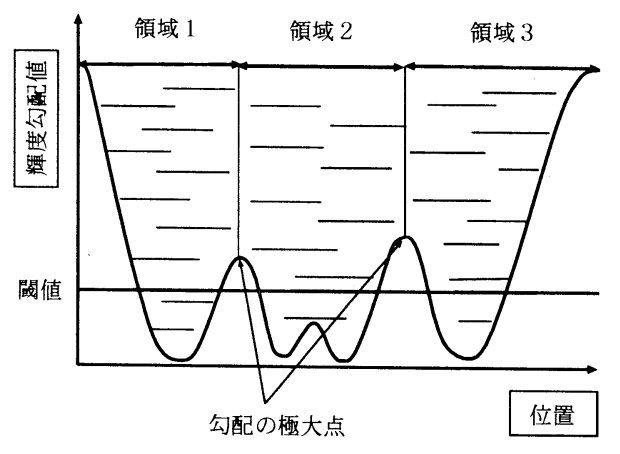

図 2 Watershed アルゴリズムの概念図 Watershed algorithm

ことで領域の境界を抽出することができる. しかし，すべ ての極大点を境界として抽出したのでは, 分割結果が過分 割になりやすい. そこで, 境界として意味のある勾配值の 最小値を閾値として設けることで勾配值の小さな境界を抽 出しないようにする. 図2のように, 勾配值が䦨値より高 い極大点にダムを作り, すべての貯水池に均一に浸水させ る. 水かさがいっぱいになったとき, 各貯水池が分割領域 になる9).

\section{3 小領域除去}

ステップ 1 の Watershed アルゴリズムを利用した境界 抽出では，閾值による制御を行ってもなお領域が過分割に なりやすい，そこで，単独でオブジェクトを構成しえない 小領域を隣接する領域に統合し，領域数を減らす。分割さ れたセグメント領域の中から面積が最小となる領域を検索 しそれと隣接する領域間の平均輝度のユークリッド距離が 最小となる領域に統合する.この処理を設定した最小領域 面積以上となるまで繰り返す.

\section{4 領域の統合}

小領域除去を終えた段階でもセグメント数は多く，1つ のオブジェクトでも複数個の領域に分割されている場合が ある. そのためにステップ 3 では隣接する 2 つの領域を統 合して良いかを表す指標（評価関数）をすべての組合せで 計算し，その値が最小となる領域同士を統合させる．領域 数が設定した最終領域数となるまで，処理を繰り返す．領 域統合を行う際の評価関数として，隣接する 2 つの領域を 仮に統合したときの動き量および輝度の平均値と統合前の 領域の平均 2 乗誤差を計算する.これは統合前と統合後で, 領域の特徵がどれだけ変化したかを表す指標となり, 統合 しても画像としての特徵 (動オブジェクトや絵柄) が失われ にくい領域同士から統合される.

\section{3. トラッキングを用いた動画像領域分割アルゴリ ズム}

2. に示した領域分割アルゴリズムではフレーム毎に独 立に処理を行うため処理量が増大し，またフレーム毎に抽 出される領域の対応関係がない. そこで, あるフレームで 分割した領域を時間軸に対して追跡 (トラッキング)し，画 


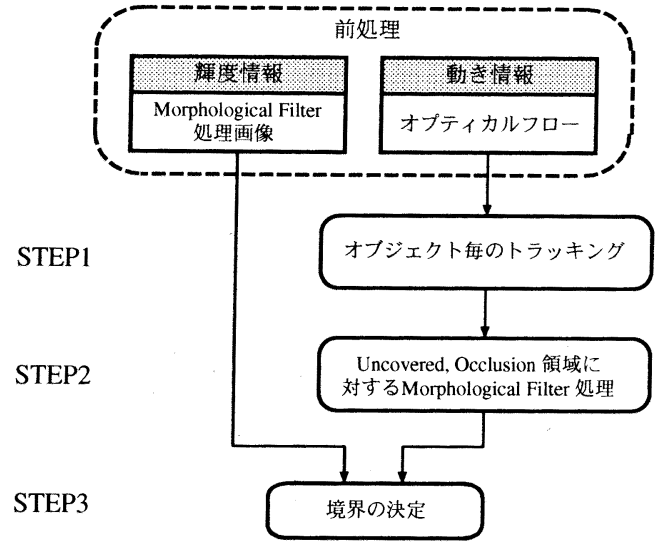

図 3 トラッキングを用いた領域分割アルゴリズム Moving objects segmentation by tracking

像シーケンスを領域分割する手法を検討する．これは図 3 に示す 3 つのステップから構成される.

\section{1 オブジェクト毎のトラッキング}

前フレームの各領域に含まれる画素毎の動きべクトルの 平均值をその領域の動き推定量とし, この平均値べクト ルで前フレームの領域を現フレームに写像し, 各々にラベ ルを割り付ける.この処理により, 現フレームでは, 前フ レームからの写像がない部分 (Uncovered 領域) や複数の 領域が重なり合う部分 (Occlusion 領域) が生じ，これらに はすべてラベル 0 を割り当てる.

\section{2 トラッキング画像に対する Morphological Fil-} ter 処理

領域の変形や拡大縮小によるオブジェクト境界の変化に 追随することを目的として，写像したトラッキング画像に 対して，オブジェクトごとに当該オブジェクトを “ 1 ”，そ れ以外を “ 0 ”とする. 2 值画像に Morphological Filter 処理を施し, 各領域を縮小し, 領域を形成する種 (seed)を 決定する.

\section{3 境界の決定}

ラベル 0 が割り振られた画素を周囲のいずれかの領域に 割り振る. ラベル0で, かつ領域に隣接している画素を調 ベ, 画素毎に隣接領域の平均輝度值との差を計算する. こ の值が閾値以下であればそのラベル 0 の画素を隣接領域に 統合する.この処理を繰り返し, 新しく領域に統合されな くなれば閾值を上げる.これをラベル 0 の画素がなくなる まで繰り返す.

\section{4. シミュレーション結果}

シミュレーションにはテスト画像 Mobile and Calendar を用いた. 40 フレーム目の原画像を図 4に, 輝度情報であ る Morphological Filter 処理画像を図 5, 動き情報である オプティカルフローを図 6に示す.

この画像はカレンダーが下方向, 汽車がボールを押しな がら左方向に動いているのをカメラが追うパニング画像で ある. そのため背景は画面に対して右, カレンダ一は右下,

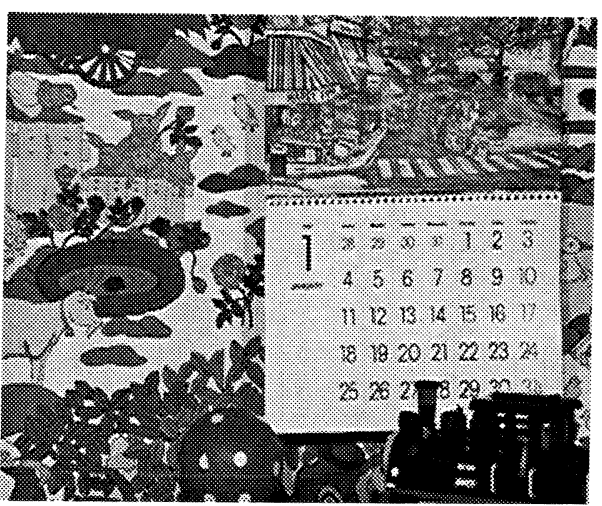

図 4 テスト画像 Mobile and Calendar40 フレーム Test image "Mobile and Calendar"

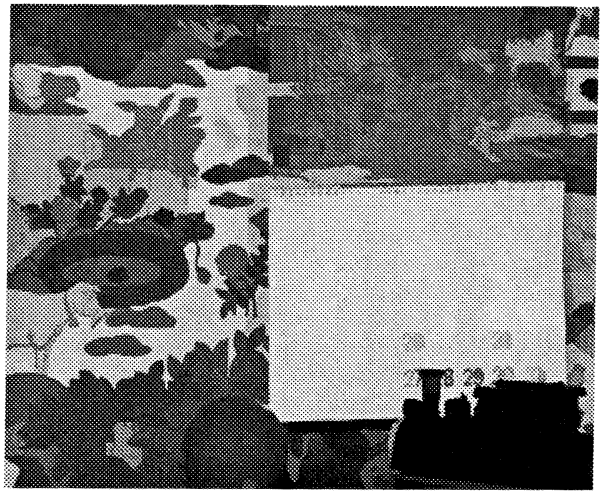

図 5 Morphological Filter 処理画像 Morphological filtered image

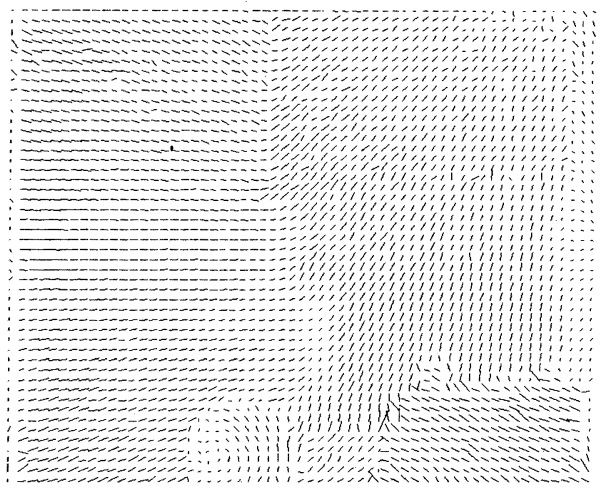

図 6 オプティカルフロー

Optical flow for test image

ボールは回転，汽車は静止している。

10 フレームから 35 フレームまで提案法を用いて領域分 割を行った結果を図 7に示す. 10 フレーム目は初期分割と して，領域統合法による領域分割を用いる．次にトラッキ ングを用いた領域分割では，トラッキングが進むにつれて 境界の誤差が蓄積されるので, 20 フレーム毎に再度, 初期 分割を挿入する. 図 $7(\mathrm{a})(\mathrm{e})$ は初期分割, (b)(c)(d)(f) は トラッキングによる分割を示す. 同図 $(\mathrm{a})$ （d) では, 初期 分割でかなり正確に境界が得られている各オブジェクトは トラッキングの進むにつれ，オブジェクトの対応関係は維 持されているものの, ボールおよびカレンダーの両端部に 


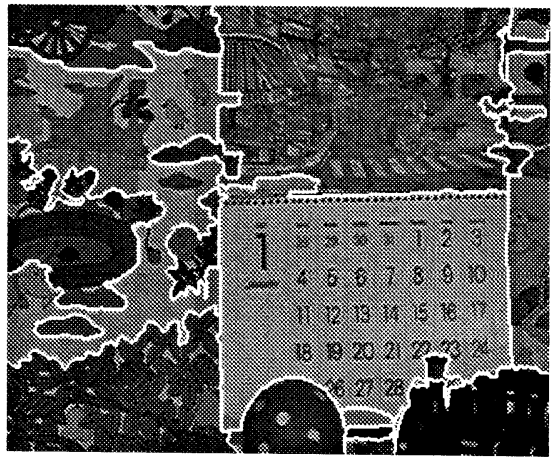

(a) 10 フレーム (初期分割)

10 frame(initial segmentation)

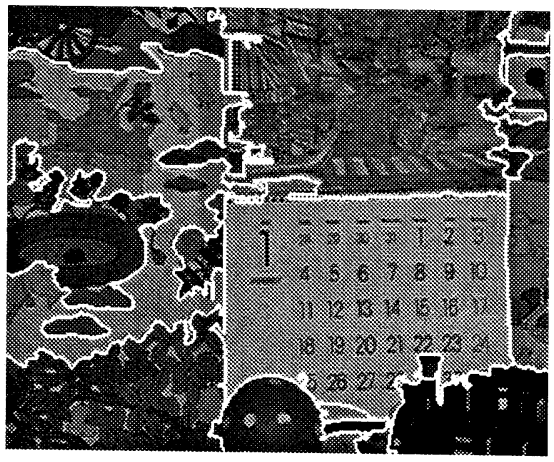

(b) 15 フレーム (トラッキング)

15 frame(segmentation by tracking)

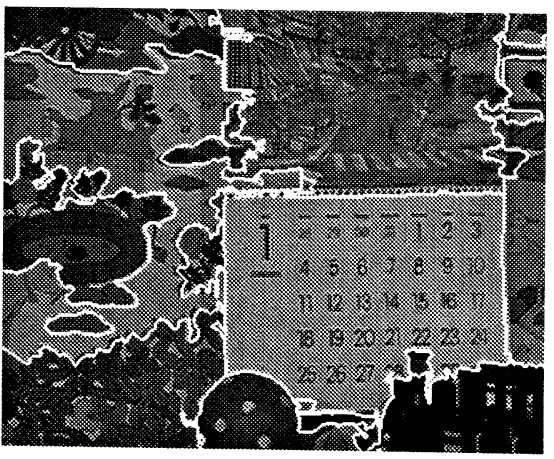

(c) 20 フレーム (トラッキング)

20 frame(segmentation by tracking)

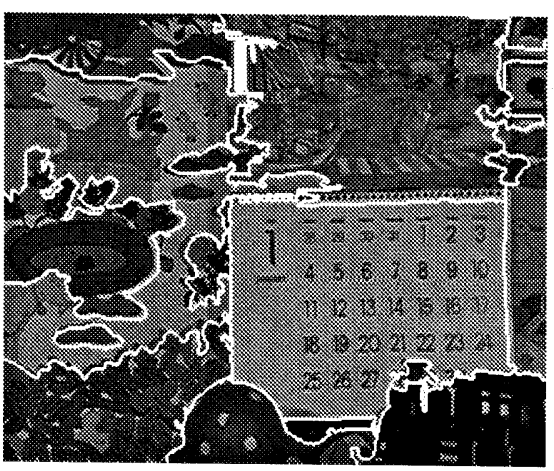

(d) 25 フレーム (トラッキング)

25 frame(segmentation by tracking)

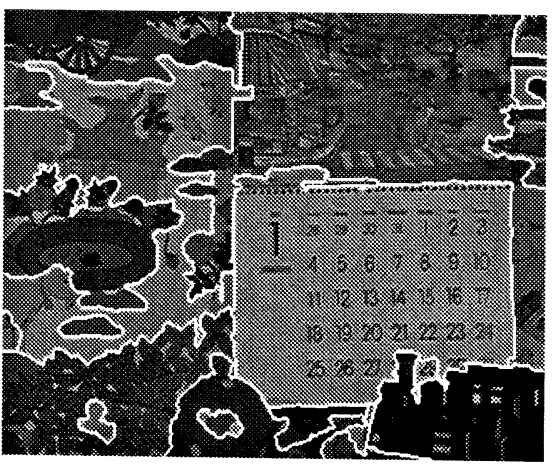

(e) 30 フレーム (初期分割) 30 frame(initial segmentation)

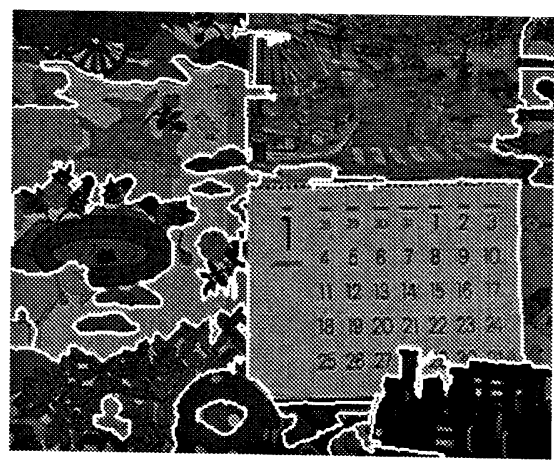

(d) 35 フレーム (トラッキング)

35 frame(segmentation by tracking)

図 7 領域分割結果

Segmentation results for test image" Mobile and Calendar"

おいて境界の不正確さやズレが生じている．図 5 に見られ るようにこれらの部分では背景輝度との差異が小さくなっ ており，このために境界の決定においてラベル 0 の画素が 誤った領域に統合されたものと考えられる. 再度初期分割 を行った同図 (e) で正確な領域境界が再現され，トラッキ ングによる誤差の累積が解消されている.しかし，(a)と (e) では分割結果が若干異なり，とくにボール中央部に新 たな領域が検出されている．これはボールの回転運動を領 域統合の評価関数に上手く組み込めていないために，回転 が速くなるとボール周辺部と中央部で異なるオブジェクト と見なされたことによる.

\section{5.むすび}

画素単位の動きベクトルであるオプティカルフローと 輝度情報を用いて任意形状の領域分割を行った。これによ り動領域だけではなく見た目にも大きく意味のある領域に 分割することができた．また，ある特定のフレームで分割 した領域をトラッキングすることにより画像シーケンスを 通して安定した領域分割を行うことができた。しかし，い ずれの手法でも領域分割の正確性と安定性の向上が望まれ る. また, オブジェクト数が変更したり, シーンチェンジ が起きた場合, 自動的に判別して再度初期領域分割を行う 処理が必要である. 


\section{〔文献〕}

1) G.D.Borshukov, G.Bozdagi, Y.Altunbasak and A.M.Tekalp, "Motion Segmentation by Multistage Affine Classification", IEEE Trans. Image Processing, 6, 11, pp. 1591-1594, Nov. 1997

2) L. Patras ,E.A. Hendriks, and R.L. Lagendijk, "Video Segmentation by MAP Labeling of Watershed Segments", IEEE Trans. Pattern Anal.Machine Intell., 23, 3, pp. 326-332, Mar. 1997

3) C.Stiller, "Object-Based Estimation of Dense Motion Fields", IEEE Trans. Image Processing, 6, 2, pp. 234-250, Feb. 1997

4) M.Kim, J.G Choi, D.Kim, H.Lee, M.H.Lee, C.Ahn and Y.Ho, "A VOP Generation Tool:Automatic Segmentation of Moving Objects in Image Sequences Based on Spatio-Temporal Information", IEEE Trans. Circuits Syst., 9, 8, pp. 1216-1226, Dec. 1999

5) J.G.Choi and S.W.Lee and S.D.Kim, "Spatio-Temporal Video Segmentation Using a Joint Similarity Mesure", IEEE Trans. Circuits Syst., 7, 2, pp. 276-285, Apr. 1997

6）池田 研二, “Watershedアルゴリズムとオプティカルフローを用いた動 領域分割法”，信学技報, IE2001-66, pp. 9-14, Sept. 2001

7) D.Cortez et al., "Image segmentation towards new image representation methods", Signal Processing:Image Communication, 6, pp. 485-498, 1995

8) B.K.P Horn and B.G.schiunck, "Determining Optical Flow", In tell., 7, pp. 185-203, 1981

9) M.Sonka, V.Hlavac, R.Boyle, "Image Processing, Analysis, and Machine Vision", PWS Publishing, pp. 186-190

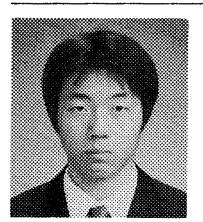

池笛研 工学部電気・情報工学科卒業. 2002 年 3 月 同大大学院 自然科学研究科博士前期課程修了. 同年, キャハン(株)

入社

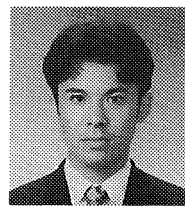

今ま哲字幸祐 1972 年生. 1995 年 3 月長崎大学 工学部電気情報工学科卒業. 1997 年 3 月 同大大学院工 学研究科修了. 2000 年 3 月 同大大学院海洋生産科学研 究科修了. 同年より，金沢大学工学部情報システムエ 学科助手. 画像信号の高能率符号化などの研究に従事. 工博.

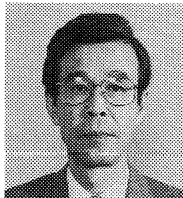

橋禁秀雄 1945 年生. 1968 年 3 月大阪大学 工学部卒業. 1970 年 3 月 同大大学院修士課程修了. 1975 年 3 月 同大大学院博士課程修了. 同年, 電電公 社 (現 NTT) 電気通信研究所入所. 以来, 画像符号化方 式，画像通信方式の研究開発に従事。現在，金沢大学 工学部情報システム工学科教授. 工博. 